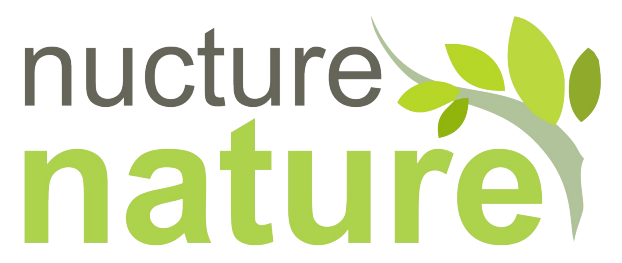

National Academic Journal of Architecture

\title{
GEDUNG BNP2TKI (BADAN NASIONAL PENEMPATAN DAN PERLINDUNGAN TENAGA KERJA INDONESIA) DI MAKASSAR
}

\author{
St. Aisyah Rahman. ${ }^{1}$ Mutmainnah ${ }^{2}$ Eko Sutrisno B. Surijadi ${ }^{3}$, \\ Jurusan Arsitektur Fakultas Sains \& Teknologi UIN-Alauddin Makassar
}

\begin{abstract}
Abstrak - Tenaga kerja dan lapangan perkerjaan masih menjadi bahasan yang menarik di Indonesia. Statistik penempatan tenaga kerja luar negeri Indonesia berdasarkan provinsi dari hasil laporan pengolahan data BNP2TKI dari periode 1 Januari (Sulawesi, Maluku, dan Papua), jumlah TKI yang bekerja di luar negeri yaitu sebanyak 817 orang. (BNP2TKI, Statistik Penempatan TKI, 2015) dan Tahun 2015 saat ini, jumlah tenaga kerja Indonesia yang akan ditempatkan bekerja di luar negeri sebanyak 120.677 orang periode 1 Januari sampai dengan 31 Mei 2015. (BNP2TKI, Statistik Penempatan TKI, 2015). Tujuan Laporan perancangan ini adalah merancang sarana dan prasarana yang mewadahi dan melindungi tenaga kerja Indonesia serta aktivitas penunjang seperti tempat pelayanan administrasi, penampungan sementara, biro konsultasi dan penempatan serta pelatihan (training) untuk peningkatan kualitas bagi para TKI yang akan bekerja di luar negeri. Hasilnya Laporan ini berupa perancangan dengan pendekatan arsitektur ekologis yang diterapkan pada teknologi bangunan yaitu dengan cara pemanfaatan bioenergi khususnya biogas sehingga dapat memberikan kenyamanan bagi pengguna bangunan. Prinsip perancangan yang digunakan ialah kesatuan atau unity yang menyatukan unsur-unsur berbeda sehingga membutuhkan suatu "pengikat" diantranya adalah permainan fasad bangunan berupa penggunaan material kaca yang dilengkapi panel surya sebagai sumber energi alternatif dan penggunaan warna antara bangunan yang seragam.
\end{abstract}

Kata kunci: BNP2TKI, arsitektur ekologis, biogas.

Abstract-.Employment and job field is still become the interesting topic in Indonesia. The statistics of the distributing Indonesia according to the results of data processing BNP2TKI province report from the period January 1 (Sulawesi, Maluku, and Papua), the number of workers who work abroad as many as 817 people. (BNP2TKI, TKI Placement Statistics, 2015) and 2015 right now the number of Indonesian workers will worked abroad as many as 120677 the period January 1 to May 31, 2015. (BNP2TKI, TKI Placement Statistics, 2015). The purpose of this report is to design the infrastructure and facilities that accommodate and protect Indonesian workers as well as supporting activities such as places of administrative services, temporary shelter, consultancy and placement agents and also training (training) to improve the quality for the workers who will work abroad. The result of this report is design with ecological architecture approach that is applied in building technology is by the using of bioenergy in particular biogas so that it can provide comfort for building users. Design principle used is unity or unity that

1Dosen Jurusan Teknik Arsitektur UIN Alauddin Makassar 2Dosen Jurusan Teknik Arsitektur UIN Alauddin Makassar

3 Alumni Jurusan Teknik Arsitektur UIN Alauddin Makassar Angkatan 2015 


\section{nucture

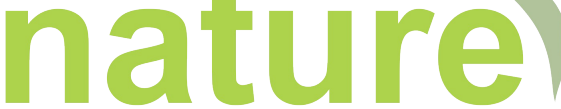

National Academic Journal of Architecture brings together the different elements that require a "binder" such as building facades game with the glass using material, incorporating solar panels as an alternative energy source and the use of uniform color between similar building.

Keywords: BNP2TKI, Ecologic Architecture, Biogas

\section{PENDAHULUAN}

Tenaga kerja dan lapangan perkerjaan masih menjadi bahasan yang menarik di Indonesia. Jumlah penduduk yang meningkat tanpa diikuti pertambahan lapangan pekerjaan selalu menjadi pemicu menjamurnya pengangguran. Masalah akan timbul, apabila terdapat kesenjangan antara jumlah tenaga kerja yang besar dengan minimnya ketersedian lapangan kerja yang ada. Dengan kata lain lapangan kerja yang ada tidak mampu menampung (mempekerjakan) tenaga kerja yang ada, terutama tenaga kerja yang tidak terampil atau berpendidikan. Hal ini akan menyebabkan semakin meningkatnya tingkat pengangguran sehingga jumlah penduduk miskin juga semakin besar dan memiliki efek-efek negatif yang lain pula.

TKI yang bekerja di luar negeri sangat membantu untuk mengurangi pengangguran yang masih banyak dan belum dapat diserap oleh keterbatasan pekerjaan di Indonesia. Secara ekonomi, TKI telah menghasilkan devisa bagi negara dan sekaligus meningkatkan kesejahteraan para TKI dan masyarakat sekitarnya. Selain itu, TKI juga menjadi duta bangsa untuk mengenalkan Indonesia di luar negeri. Namun pengiriman TKI ke luar negeri harus tetap menjaga harga diri dan martabat bangsa Indonesia. (Jurnal Kajian Lemhannas RI, Grand Design Pelaksanaan TKI Ke Luar Negeri guna Menjaga Harkat dan Martabat Bangsa dalam Rangka Ketahanan Nasional, 2013)

Sepanjang tahun pemerintah Indonesia harus dipusingkan dengan permasalahan TKI. Selain itu, pemerintah juga bermasalah dengan negara- negara seperti Malaysia dan Singapura karena kasus-kasus kekerasan yang diterima oleh TKI. Namun tetap tidak ada solusi dan kebijakan yang tepat sasaran dan mampu mengatasi permasalahan TKI ini. Setiap kebijakan yang dikeluarkan pemerintah menuai protes dari banyak kalangan aktivis perempuan, akademisi dan pemerhati TKI. Sehingga seolah kebijakan yang sudah ada mengambang begitu saja tanpa tindak lanjut, sementara nasib para TKI semakin tragis dan terkesan dibiarkan.

Penyaluran TKI khusus untuk wilayah Indonesia Timur (Sulawesi, Maluku, dan Papua), BNP2TKI memusatkannya di Provinsi Sulawesi Selatan tepatnya di Kota Makassar, hal ini dikarenakan Provinsi Sulawesi Selatan merupakan pusat dari wilayah Indonesia bagian timur.

Memasuki Masyarakat Ekonomi Asean 2015, negara-negara Asean sepakat membuka kesempatan tenaga-tenaga kerja masuk ke sesama negara anggota. N Indonesia dengan pertumbuhan ekonomi yang tinggi, diperkirakan menjadi salah satu tujuan negara yang diminati tenaga kerja asing. Tahun 2015 saat ini, jumlah tenaga ๘ kerja Indonesia yang akan ditempatkan bekerja di luar negeri sebanyak 120.677 orang $\frac{\pi}{\pi}$ periode 1 Januari sampai dengan 31 Mei 2015. (BNP2TKI, Statistik Penempatan TKI, 2015)

Data yang telah dikemukakan di atas, menggambarkan pentingnya sebuah tempat yang dapat memberikan pelayanan kepada TKI khususnya untuk kawasan Indonesia bagian timur. Olehnya sangat diperlukan desain perancangan Gedung BNP2KI di Makassar sebagai sarana dan prasarana yang mewadahi dan melindungi tenaga 


\section{nucture \\ nature}

National Academic Journal of Architecture

kerja Indonesia di luar negeri. Gedung ini akan berfungsi sebagai tempat pelayanan administrasi, penampungan sementara, biro konsultasi dan penempatan serta pelatihan (training) untuk peningkatan kualitas bagi para TKI yang akan bekerja di luar negeri.

Penggunaan kebutuhan ruang yang sesuai dengan standar dan sirkulasi yang ideal sangat diperlukan guna memberi kenyamanan bagi pengguna bangunan terutama asrama bagi para TKI dengan mengaplikasikan pendekatan arsitektur ekologis ke dalam desain dengan cara pemanfaatan bioenergi khususnya biogas. Nantinya, pengaplikasiaan pendekatan ini dapat memberikan kenyamanan bagi pengguna bangunan.

\section{METODE PENULISAN}

Langkah-langkah yang dilakukan dalam metode pembahasan ini yaitu:

A. Pengumpulan data, diperoleh berdasarkan tiga proses studi, yaitu: studi literatur, studi preseden, dan studi lapangan

a. Studi literatur, yang dilakukan untuk mengumpulkan pemahaman dan mendalami permasalahan mengenai tema yang diambil dan pendekatan yang akan diterapkan pada desain bangunan. Studi literatur mengenai standar akan kebutuhan ruang dilakukan agar memperoleh pemahaman mengenai faktor faktor pendukung persyaratan teknis bangunan.

b. Studi preseden, dengan melakukan studi komparasi atau perbandingan terhadap bangunan- bangunan sejenis yang ada sebagai suatu bahan perbandingan untuk memperoleh masukan yang dapat diterapkan pada rancangan dan memperoleh pemahaman mengenai faktor-faktor pendukung persyaratan teknis bangunan.

c. Studi lapangan, yaitu melakukan survey lokasi untuk mengumpulkan informasi mengenai potensi-potensi fisik dan non-fisik lokasi perancangan bangunan.

B. Pengolahan data, dengan mengintegrasikan teori-teori yang berkaitan dengan objek perancangan untuk dilakukan analisis.

a. Tahap analisis, yaitu melakukan analisis dari data yang telah terkumpul dan diolah ke dalam sebuah konseptual perancangan.

b. Hasil desain, berdasarkan hasil dari analisis konseptual sehingga menghasilkan rancangan Gedung BNP2TKI dengan penerapan arsitektur ekologis berupa teknologi bioenergi khususnya biogas.

\section{KONSEP DESAIN}

\section{A. Konsep Desain Tapak}

Tapak didesain dengan sistem sirkulasi yang terpisah antara kendaraan pegawai atau karyawan dengan pengunjung atau masyarakat umum. Hal ini bertujuan guna memberi kenyamanan akses di dalam tapak. Selain itu, tapak juga menjorok masuk ke dalam dari jalan utama (Jalan Perintis Kemerdekaan) dengan perantara bangunan komersil (ruko).

Ukuran tapak yang cukup luas memberikan spasi antara bangunan dengan ruang terbuka hijau sehingga menamabah kesan ekologi pada tapak/site serta 


\section{nucture 10 nature}

National Academic Journal of Architecture bangunan. Daerah terbuka hijau yang lebih luas lebih mempermudah dalam penyerapan air ke dalam tanah.

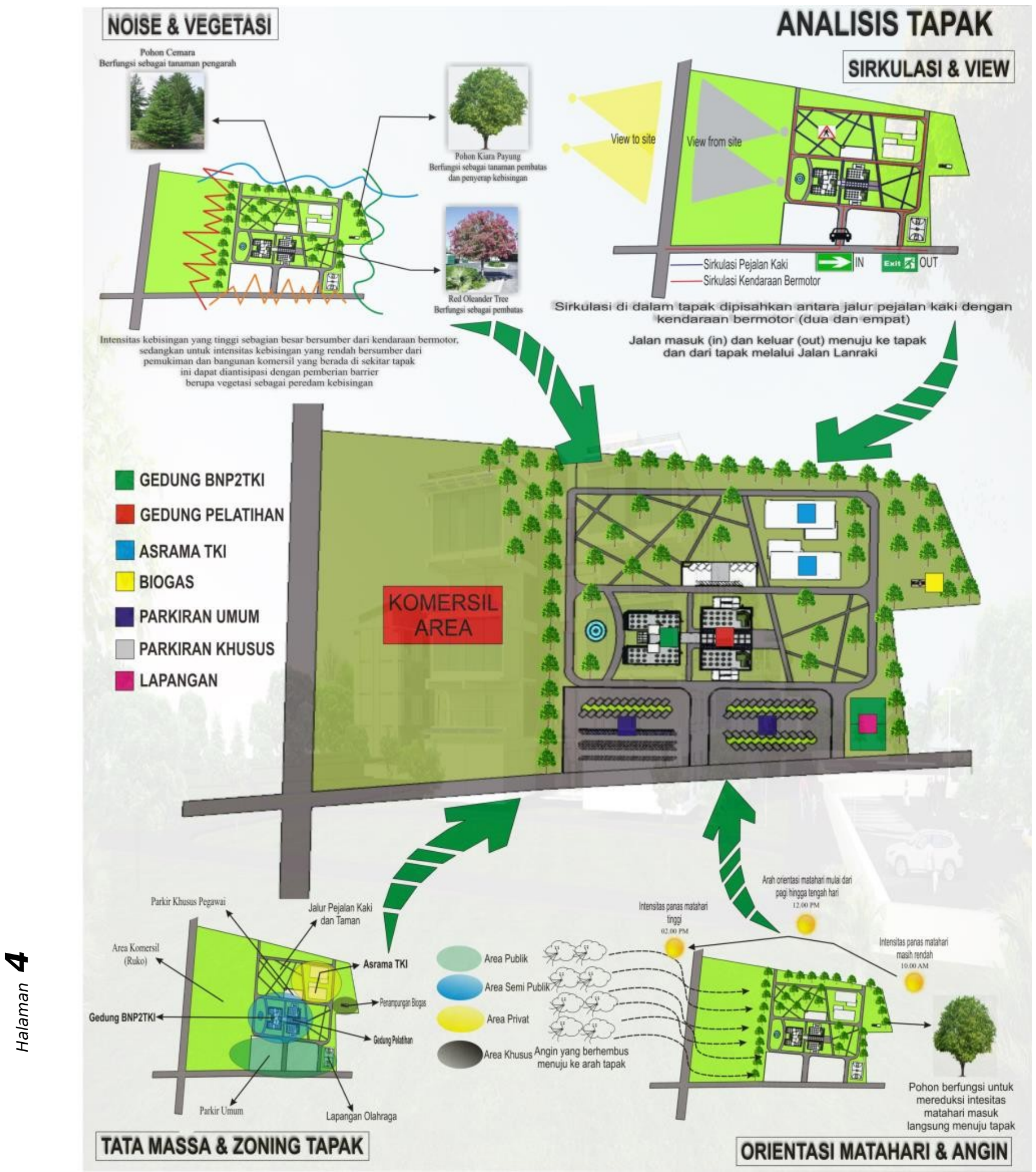




\section{nucture naturel}

National Academic Journal of Architecture

Gedung BNP2TKI didesain bermassa guna menggambarkan kesan ekologi dan pemanfaatan lahan secara optimal tanpa mengabaikan fungsi utama dari bangunan. Gedung BNP2TKI ini tidak hanya terfokus pada proses administrasi namun juga pada proses pelatihan dan tempat hunian sementara bagi para calon TKI sebelum diberangkatkan ke negara tujuan calon TKI tersebut.

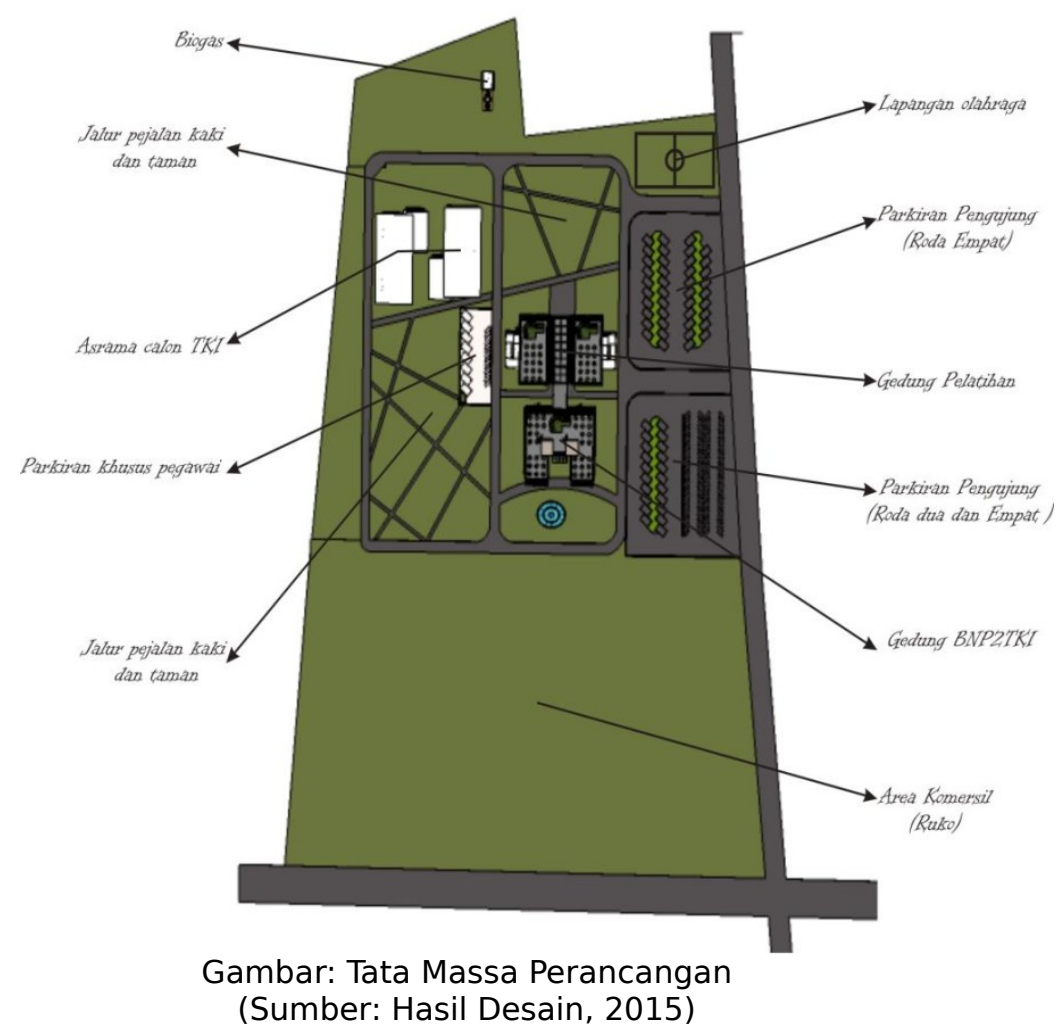




\section{nucture nature}

National Academic Journal of Architecture

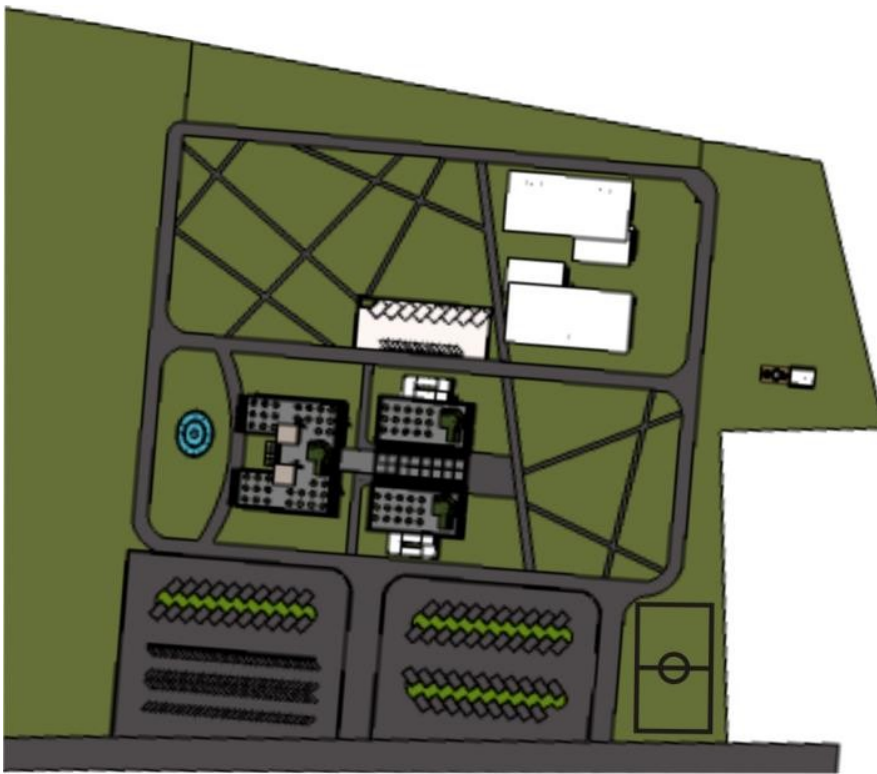

Hasil desain:

Luas total tapak perancangan: 31.855

Luas bangunan hasil desain:

7.113.65

Persentase terbangun:

$7.113 .65 / 31.885 \times 100=$

$22.33 \%$, dibulatkan menjadi $20 \%$.

Luas open space:

$31.855-7.113 .65=24.741 .35$ presentase open space : $24.741 .35 / 31.885 \times 100=$ 77.67 , dibulatkan menjadi $80 \%$.

Gambar: Site Plan

(Sumber: Hasil Desain, 2015)

\section{B. Konsep Desain Bangunan}

Gedung BNP2TKI merupakan bangunan kantor pemerintahan yang umumnya berbentuk dasar simetris yang sesuai dengan fungsi utama gedung yaitu pelayanan publik. Untuk itu, pada proses desain bangunan ini juga mengambil pilsofi bentuk tersebut disamping juga mempertimbangkan kondisi tapak dalam perencanaanya. 


\section{nucture naturel}

National Academic Journal of Architecture

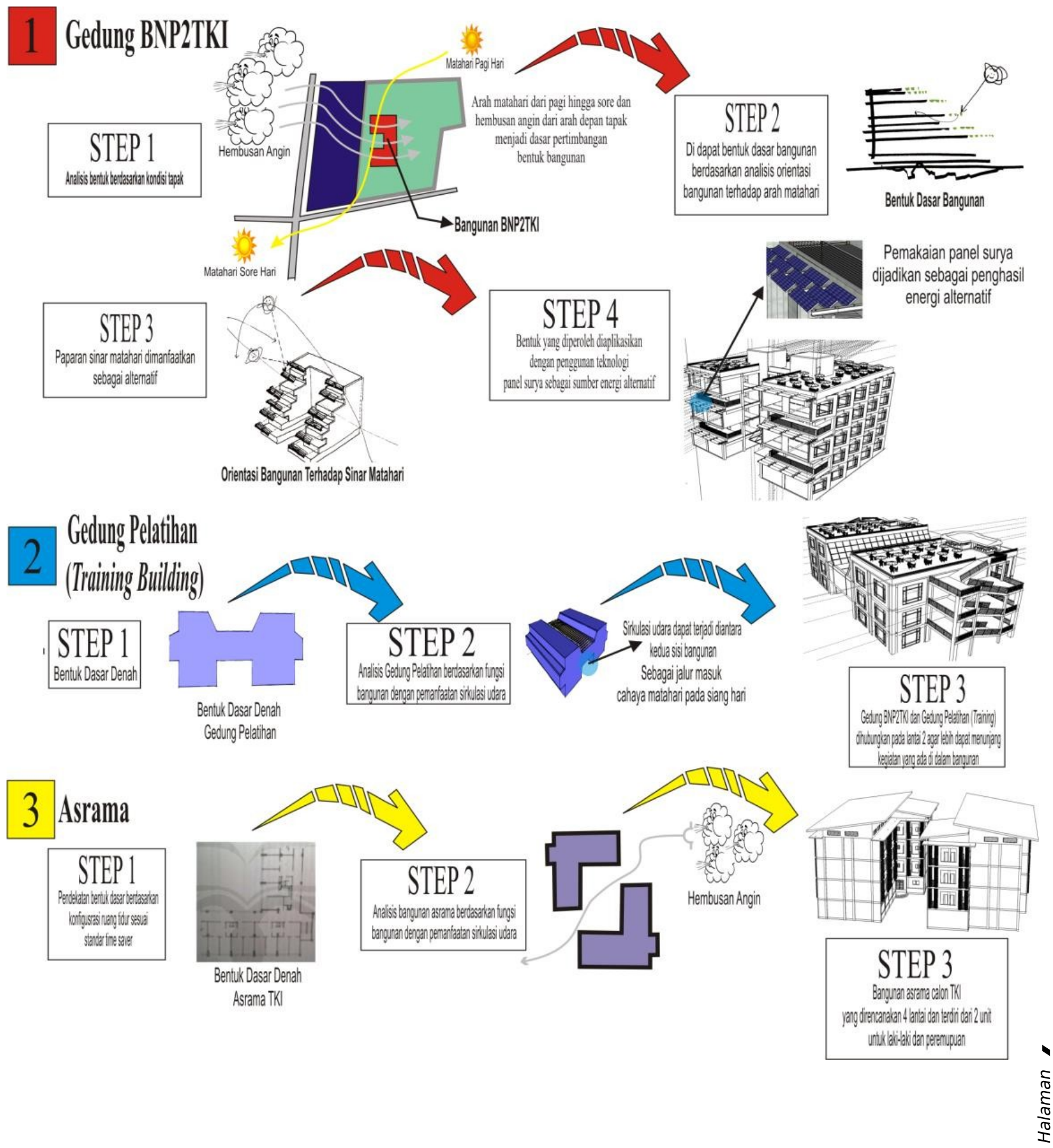




\section{nucture a nature}

National Academic Journal of Architecture

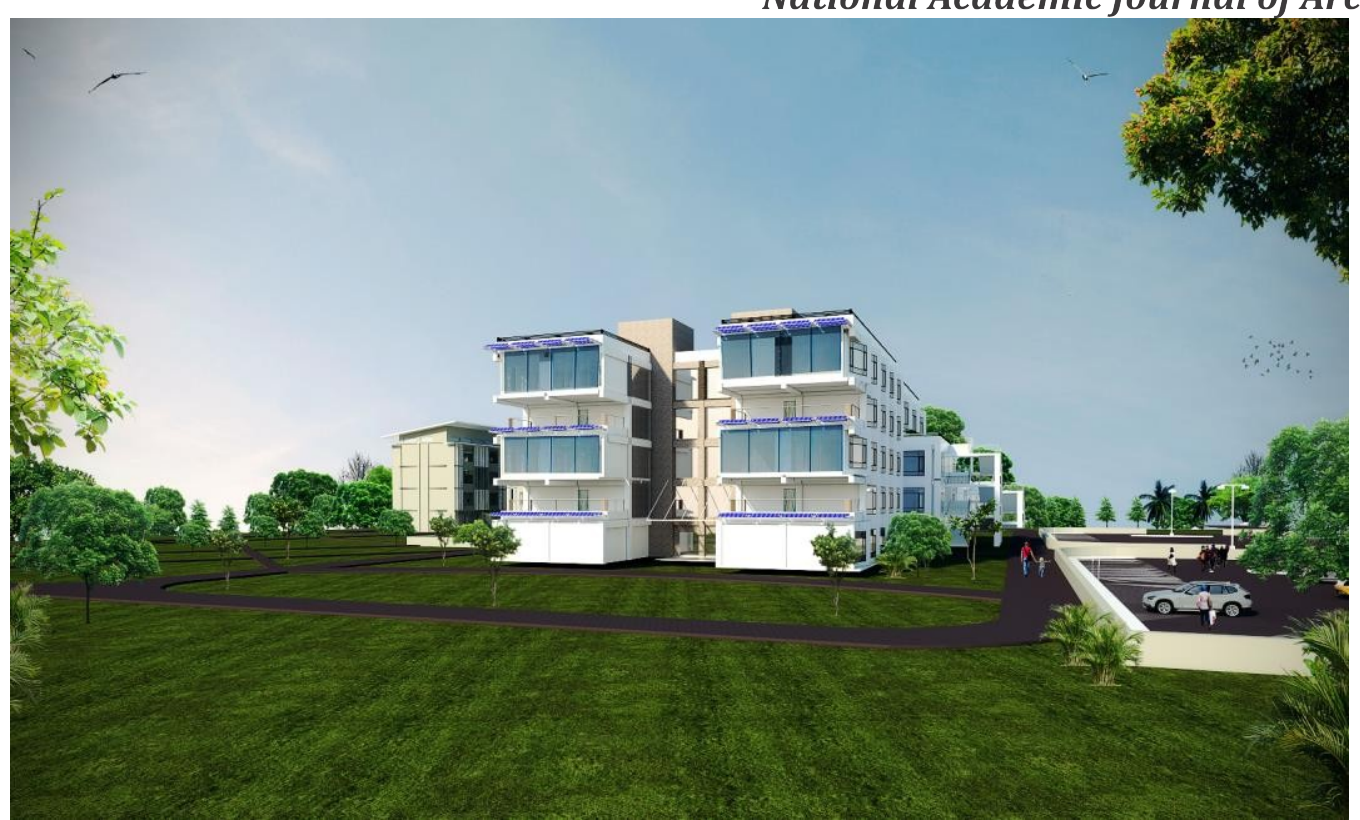

Gambar: Desain Bangunan

(Sumber: Hasil Desain, 2015)

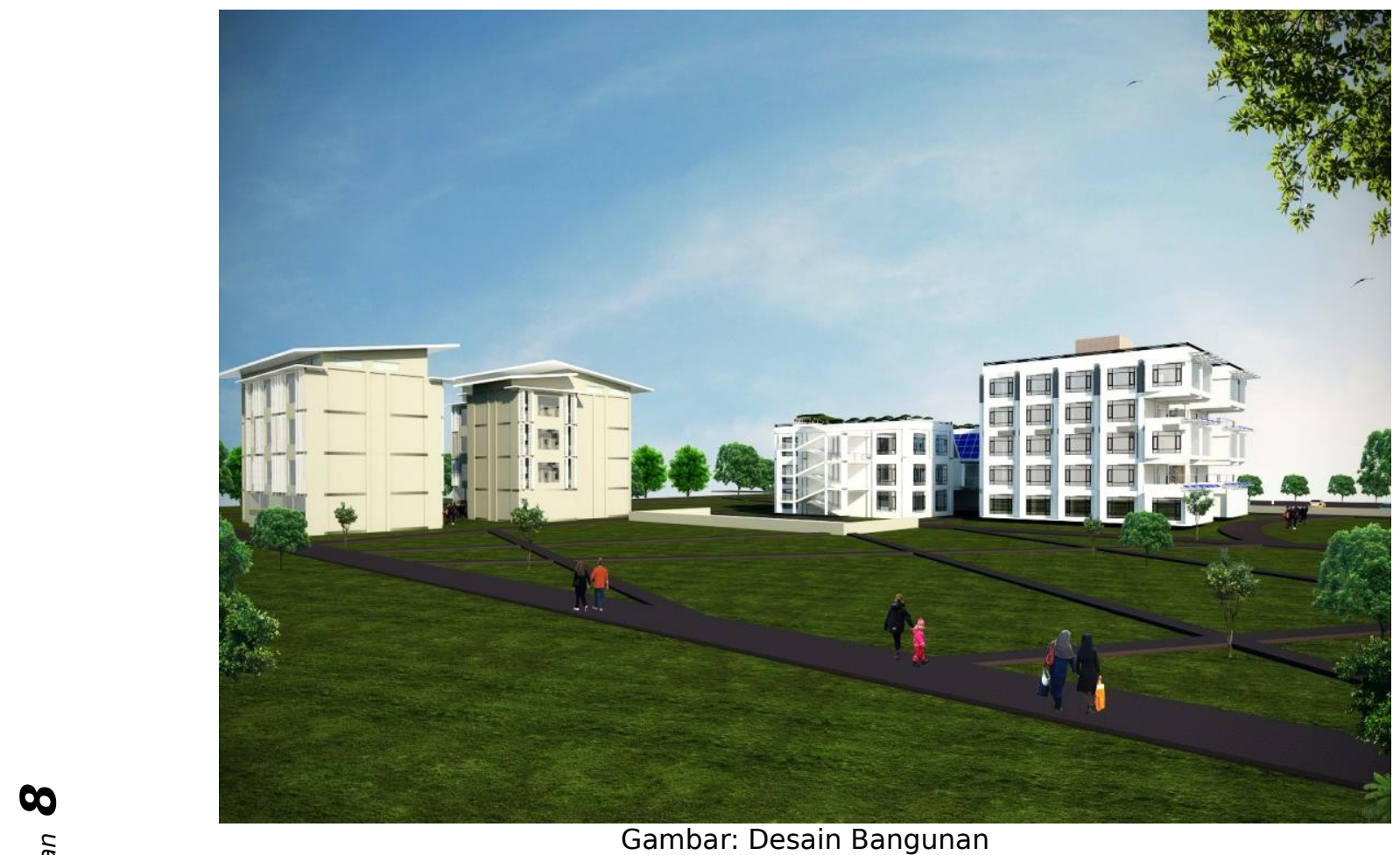

(Sumber: Hasil Desain, 2015)

\section{Konsep Sistem Struktur Bangunan}




\section{nucture}

National Academic Journal of Architecture

Bangunan Gedung BNP2TKI digolongkan ke dalam bangunan berlantai menengah (5 lantai), gedung pelatihan (3 lantai) dan asrama TKI (4 lantai) dengan bentuk simetris menggunakan tipe struktur pondasi tiang pancang dan pondasi poer sebagai super struktur, baja prefabrikasi sebagai super struktur, dan baja konvensional sebagai upper struktur.

Material yang dipakai pada bangunan ini adalah material-material pabrikasi yang dibuat khusus seperti aluminium composit panel berpori, baja $\mathrm{H}$ beam pengikat panel surya dan dinding granit.

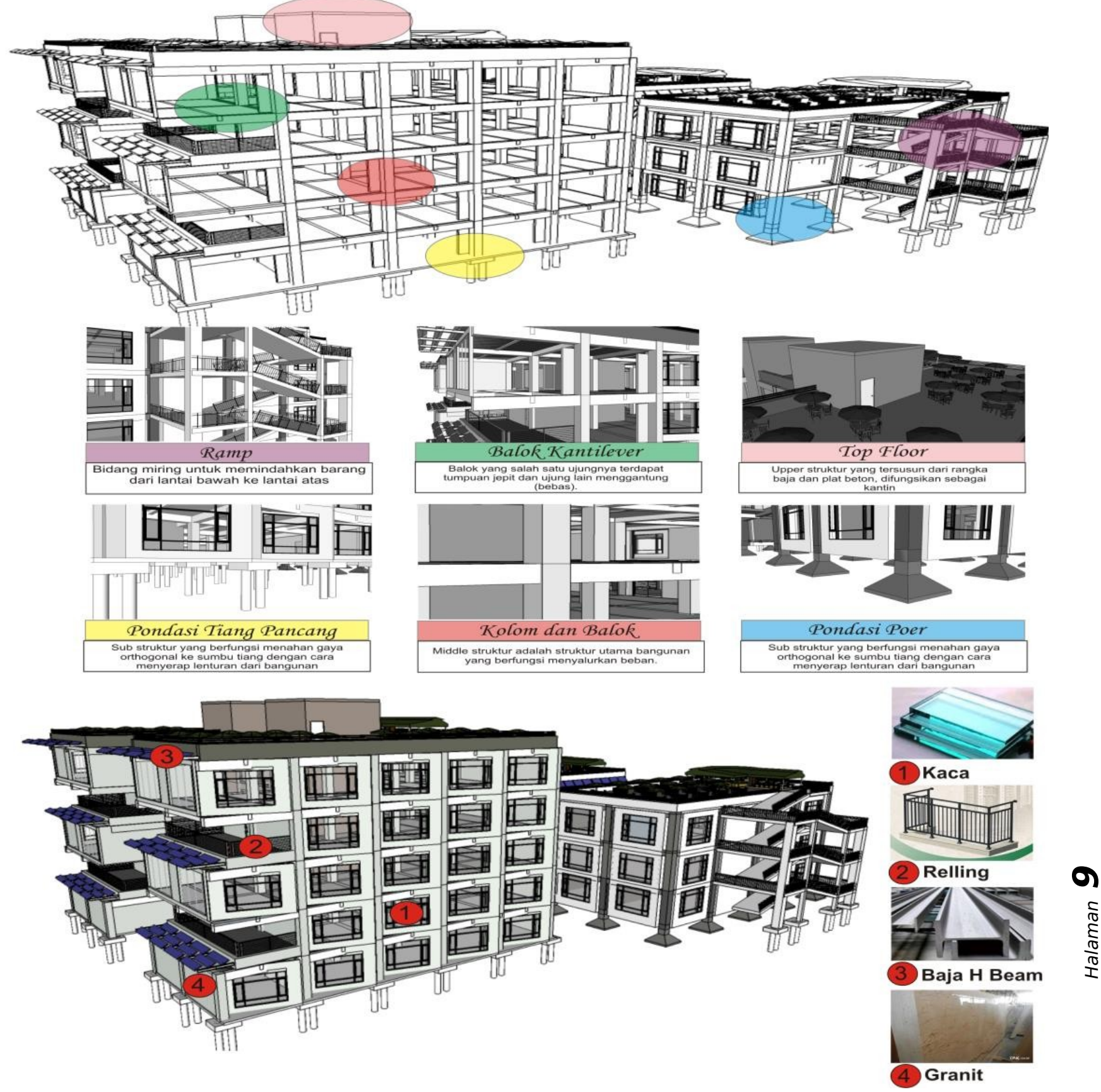




\section{nucture

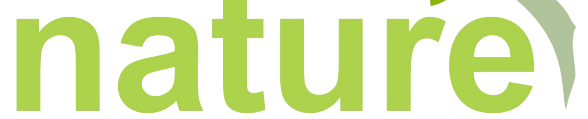

National Academic Journal of Architecture

D. Konsep Pendekatan Teknologi (Arsitektur Ekologis)

1. Panel surya, Ekspose struktur dan Ramp

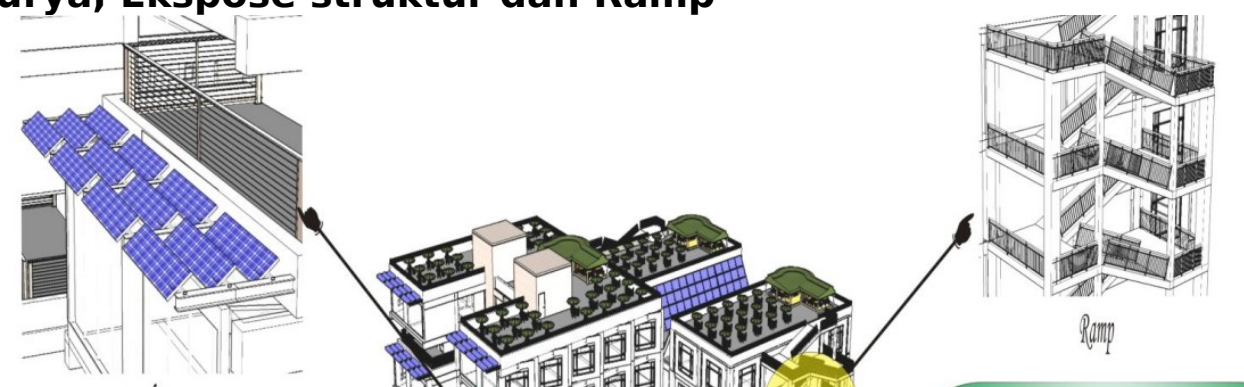

Pandelima

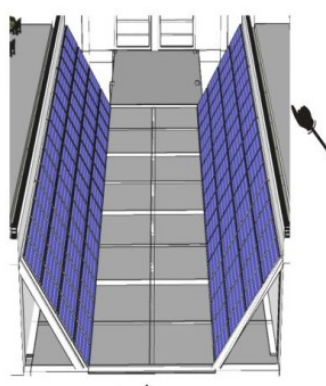

Pancliana

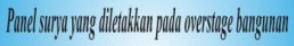

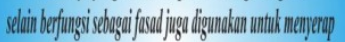

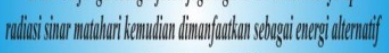
pentonglihit tengan listik.

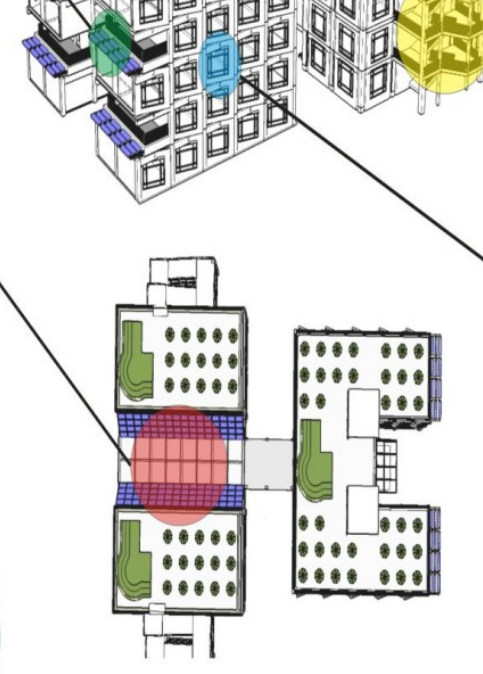

4. Befurgo

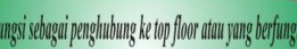

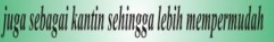

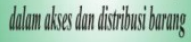

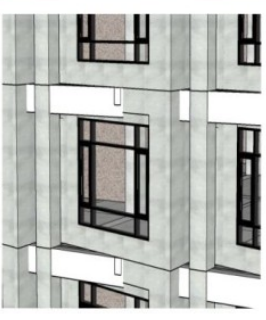

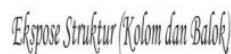

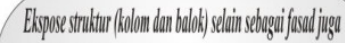

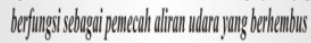
melduibunguman

\section{Biogas}




\section{nucture}

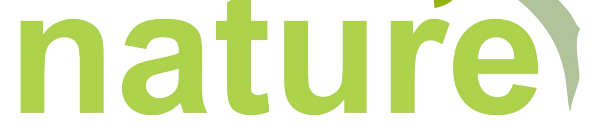

National Academic Journal of Architecture

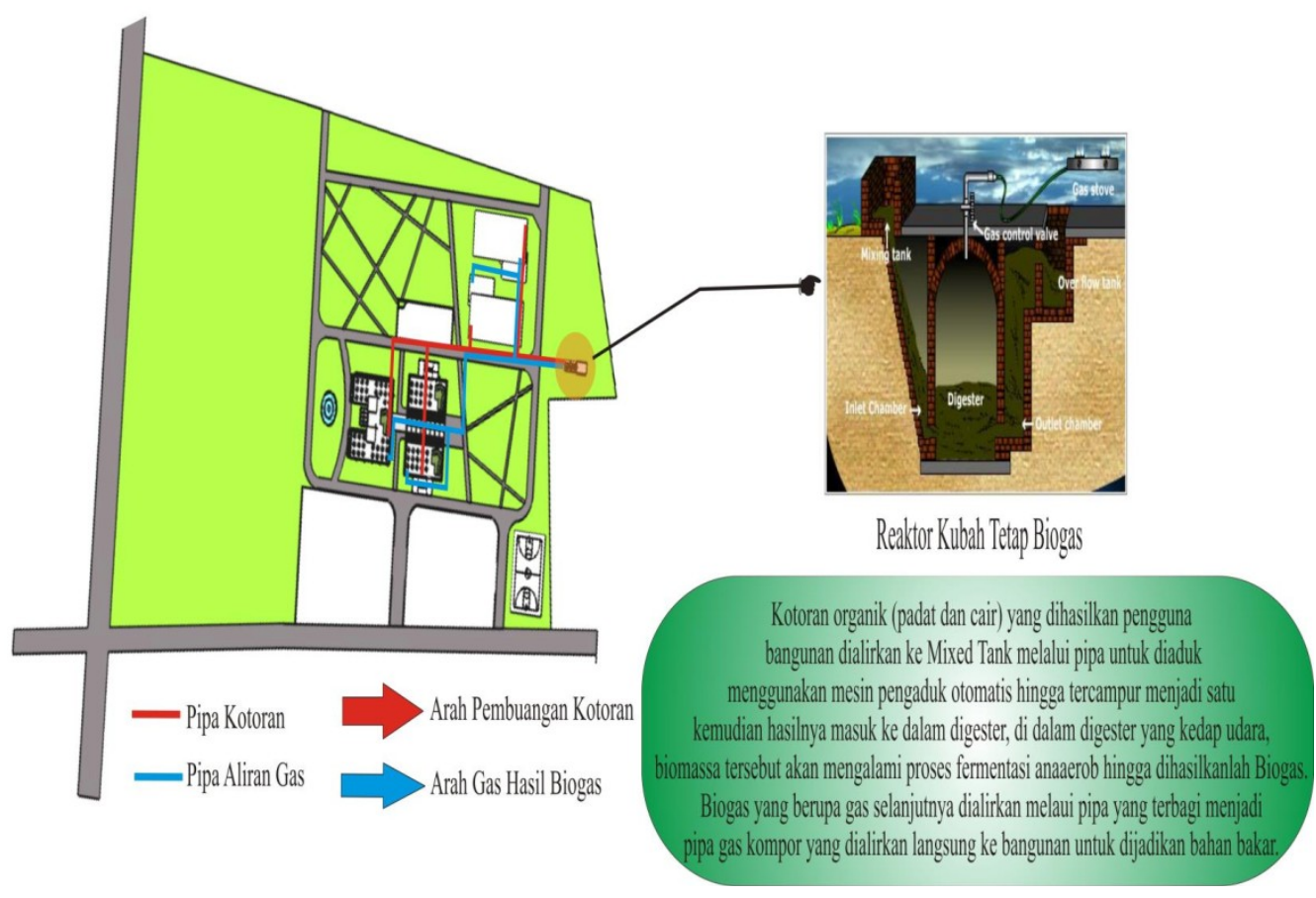

\section{KESIMPULAN}

Gedung BNP2TKI (Badan Nasional Penempatan Dan Perlindungan Tenaga Kerja Indonesia) di Makassar ini sangat dibutuhkan sebagai sarana dan prasarana yang mewadahi dan melindungi tenaga kerja Indonesia ke luar negeri. Penerapan arsitektur ekologis ke dalam desain dengan cara pemanfaatan bioenergi khususnya biogas sebagai sumber energi alternatif yang ramah lingkungan dan terbarukan. Selain itu gedung ini juga dirancang berdasarkan kebutuhan ruang yang sesuai dengan standar dan sirkulasi yang ideal sangat sehingga memberi kenyamanan bagi pengguna bangunan terutama pada gedung asrama bagi para calon Tenaga Kerja Indonesia (TKI).

Dibutuhkan sebuah kajian lebih mendalam mengenai arsitektur ekologis yang holistic (menyeluruh).Terkhusus pada dunia arsitektur mengeni waktu prediksi masa penggunaan bangunan Gedung BNP2TKI sehingga dapat diperidiksi mamfaat yang dihasilkan untuk energi sendiri dan lingkungan sekitar

\section{DAFTAR PUSTAKA}

De Chiara, Joseph \& Callendar, John. 1990. Time Saver Standards for Building Types 3rd edition , McGraw-Hill Publishing Company

Departemen Agama RI. 2002. Mushaf Al-Qur'an Terjemah. Jakarta: Pena IImu dan Amal.

Frick, Heinz. Suskiyatno FX Bambang. Arsitektur Ekologis. Yogyakarta: Penerbit Kanisius. 2006.

Frick, Heinz. Suskiyatno FX Bambang. Dasar-Dasar Arsitektur Ekologis. Yogyakarta: Penerbit Kanisius. 2007.

Frick, Heinz. Suskiyatno FX Bambang. Dasar-Dasar Eko-Arsitektur. Yogyakarta: Penerbit Kanisius. 1998.

Gassing, Qadir dan Wahyudin Halim. Pedoman Penulisan Karya Tulis Ilmiah. Makassar: Alauddin Press Makassar, 2009.

Guzowski, Mary. Towards Zero Energy Architecture New Solar Design. London: Laurence King Publishing Ltd, 2010. Lieberman, P. M. (1976). Personal Remembrance. SB 1976, 8.

Nawir, Yahya. Acuan Perancangan Pusat Pelatihan Autodesk Dengan Pendekatan Hemat Energi Di Makassar. Makassar: UIN Alauddin Makassar, 2012. 


\section{nucture naturel}

National Academic Journal of Architecture

Neufert,Ernest: 1997. Data Arsitek Jilid 2. Jakarta: Erlangga.

Neufert,Ernest; 1997. Data Arsitek Jilid 1. Jakarta: Erlangga. Bany Chaerwansyah, dkk

Neufert,Ernest. Architect's Data. Second. Dialihbahasakan oleh Sjamsu Amril. Jakarta: Erlangga, 1991.

Pemerintah Kota Makassar badan perencanaan pembangunan daerah, Rencana Tata Ruang Wilayah Kota Makassar 2010-2030.Pdf

Safamanesh, Kamran. Menara Mesiniaga. Kuala Lumpur: Technical Review

Summary, 1995.

Shihab, M. Quraish. Tafsir Al-Mishbah. Tanggerang: Lentera Hati, 2002. Widiastuti. (1995). Psikologi Penghuni Asrama. 5 Wong, Wicius. Beberapa Asas Merancang Trimatra / Wucius Wong, terjemahan

Adjat Sakri. Bandung: Penerbit ITB, 1989.

\section{Website:}

https://earth.google.com/

http://ppid.bnp2tki.go.id/index.php/kedudukan-tugas-dan-fungsi (diakses pada 31 Juli 2014).

http://www.bnp2tki.go.id/ (diakses pada 31 Juli 2014).

http://finifio.wordpress. com/category/arsitektur-dan-lingkungan/, (diakses pada 21 September 2014).

http://kbbi.web.id/gedung (diakses pada 12 September 2014). http://www.planet-biogas.co.uk/biogas/info/, 2015

http://www.konsultasik3.com/p/keselamatan-dan-kesehatan-kerja.html, (diakses pada 21 September 2014).

http://www.solaripedia.com/13/302/3408/menara_mesiniaga_exterior.html (diakses 21 September 2014).

http://www.astudioarchitect.com/2010/02/arsitektur-tropis-bāngunan-tinggi- ken.html\#ixzz3CWGfd2vx (diakses 21 September 2014).

https://vnre.wordpress.com/category/hochiminh/page/7/(diakses 15 Maret 2014). 